CHAPTER 8

\title{
Conclusion: Shifting Boundaries of Genre and Community
}

The focus of this book has been to identify key principles of indigenous genre identification and organization within what is identified as a "Chhattisgarhi" repertoire. A complete ethnography-of-speaking analysis of the performance repertoire of Chhattisgarh would go beyond this marked repertoire to include pan-Indian traditions, privately performed and conversational genres such as folktale, proverb, and jokes. My purpose has not been such an exhaustive analysis of the performance repertoire and rules of usage but to ask what difference the frame of indigenous genres and the principles of organization within the marked repertoire make to the reception and interpretation of performance.

In this conclusion, we shift to a consideration of the levels of identification of genre and community and the significance and fluidity of those boundaries within the Chhattisgarhi repertoire. Using the indigenous principle of the social organization of genre and repertoire, three analytic levels of folklore community in Chhattisgarh can be identified, through which some of this fluidity can be accounted. The first level I identify as the folklore group; and it is this level that is most frequently associated with specific genres by Chhattisgarhi informants. The folklore group identifies the performers themselves; they are the singers, players, or dancers, and, for some genres, also the audience. The folklore group may be identified by combination of social variables: caste, age, gender, and marital status. While membership in some groups is relatively stable (such as those dependent on caste and gender), membership in others (dependent on marital status or age) is temporary. The stability of some folklore groups may be even more fleeting, such as the folklore group (a multicaste audience whose members may come from sev- 


\section{I78 Gender and Genre in the Folklore of Middle India}

eral villages) created through the performance of a professional performer for the duration of a single night's performance. These performers, like the kathāni kūhā storyteller and the Oriya bāhak singer/dancer have the skill to manipulate an audience into a cohesive body, which afterward dissipates again into diverse groups based on gender, caste, and village.

While primary folklore groups can usually be identified through indigenous oral commentary and metafolklore, such commentary does not always articulate "nontraditional" or newly emerging performance settings and participants; close ethnographic observation reveals unarticulated "rules of usage," the flexibility of the system of genres and identities of the folklore group. Local commentary consistently identifies dâlkhāì, for example, with unmarried girls, but in contemporary performance, men and married women have begun singing the songs of the festival outside of that ritual context. The fact that the songs are identified as "bad" (burī), as well as belonging to unmarried girls, provided a clue toward the existence of their nonfestival performance context.

The second analytic level of community identified through performance is what I have called the folklore community, a term and definition adapted from Dell Hymes's "speech community" (1974a:5 I). For analytic purposes, identification of this community is the most interesting of the three, although it is one rarely verbally distinguished from that of "region" by members of the community itself. The folklore community is one that shares both the knowledge of a particular folklore repertoire and the rules by which its members communicate through those genres. Members of a given folklore community know and agree upon who is traditionally permitted to perform particular genres and under what circumstances. I include the word "traditionally" here because with the spread of mass media communication and modern literacy, some of these rules are changing and their regulation is not always clear.

A third level of community identified through performance is that of the folklore region, the largest social and geographic grouping and, as mentioned above, one that is self-consciously expressed by inhabitants of Chhattisgarh. The folklore region is characterized by a shared repertoire of performance genres but not necessarily by identical rules of usage for those genres. A single region may be composed of numerous folklore communities whose repertoire of genres is similar but whose performance contexts and "rules" may differ. In many ways, a folklore region is "imagined" in the same way that, according to Benedict Anderson, the nation is an "imagined community," because the members of the community "will never know most of their fellow-members, meet them, or even hear of them, yet in the minds of each lives the image of their communion" (I983:I5). 


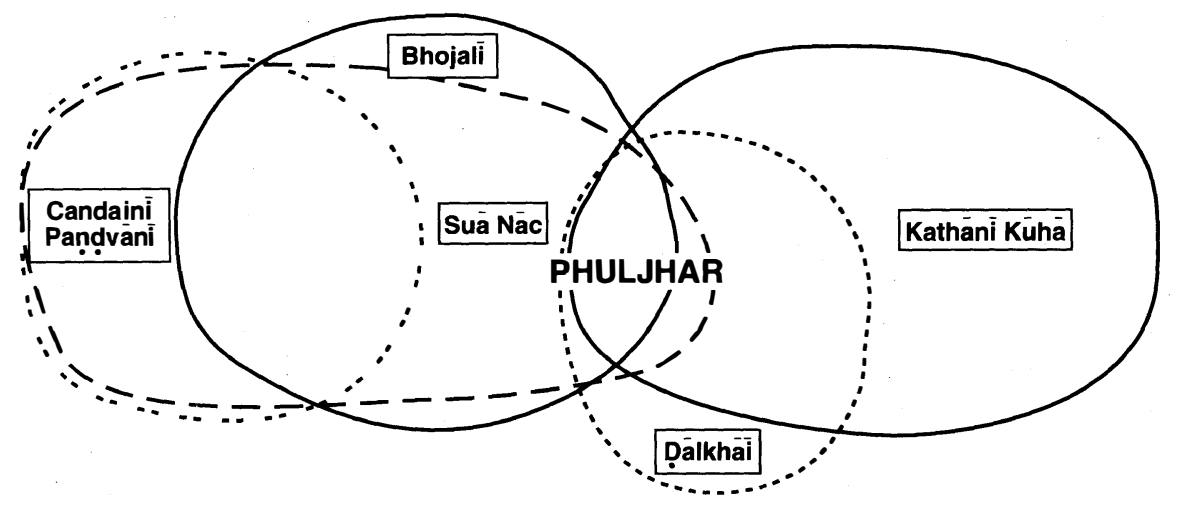

CHHATTISGARH
FOLKLORE REGION

WESTERN ORISSA FOLKLORE REGION

Map 2. Isogenres indicating the Chhattisgarhi and western Orissa folklore regions

The regional repertoire of "Chhattisgarhi" folklore, many of whose genres are said to be of tribal (particularly Gond) origin, was not difficult to determine. Pan-Indian traditions, such as rämlìta performances of the Ramayana epic or bhajan devotional songs, were rarely, if ever, mentioned as part of this repertoire. Although members of the folklore region have a sense of a bounded region, to determine its geographic borders is more difficult. One can conceptualize, however, "isogenres" (equivalent to the isogloss of linguistic studies) for each genre of the regional repertoire, showing the relative geographic spread of its performance. The repeated overlap of such isogenres begins to build up the rough outlines of the folklore region (see Map 2 for a geographic conceptualization of the genres analyzed in this study). The process of delineating a folklore region is particularly revealing on the border areas between two regions, where selected isogenres of each region overlap. In Phuljhar it is exactly this overlap between Chhattisgarhi and Oriya language and folklore genres that contributes to the definition to the subregion.

While performers and audience members of individual folklore communities in Chhattisgarh have a strong sense of the folklore region, they rarely differentiate between "region" and "community" as I have defined them. They assume that the folklore repertoire of their local community is spread throughout the region and that its genres are regulated by similar rules of usage. Performers and audience members alike were surprised and sometimes disbelieving when I reported to them the degree of variation in rules of usage between various folklore communities I had visited in the course of 
my fieldwork. ${ }^{1}$ The extent of variation between Chhattisgarhi folklore communities became apparent to me only as I lived in and traveled between villages and towns in both the border area of Phuljhar and the central plains around the city of Raipur. The greatest degree of variation between rules of usage for the genres considered in this study is that of the bhojali festival and song tradition examined in Chapter 2. The song tradition can be identified as a single genre through its terminology, its festival context, and repeated formal and thematic features of its songs. However, the social identification of the genre, the folklore group with which it is identified in each area (unmarried girls in Phuljhar and married women in the Raipur plains), and coexisting rules of usage create unique interpretive frames and intertextual relationships for the genre as it is performed in the two distinct geographic areas and folklore communities.

\section{Levels of Inclusivity in the Social Organization of Genre}

Although a genre can often be identified through performance with a single folklore group, rarely does an exclusive one-to-one correspondence exist between a genre and a specific folklore group in local commentary and conversations about that genre. The nature and inclusivity of the folklore group and/or community with which a particular genre is identified shifts depending on the identity of the speaker and listener and the social or performative context in which the statement is being made.

In the Chhattisgarhi dialect, the pronouns "we" or "our" (ham, hamārā) are used for both the singular and the plural; ${ }^{2}$ the words' inclusivity varies according to the context in which a statement is made. As suggested in my introduction, it took some time for me to catch the nuances of these levels of inclusivity. Anthony Cohen (1982) identifies similar variation of inclusivity in place-related identity in British rural communities as "ascending and descending 'levels.' " He finds that each ascending level simplifies and thereby increasingly "misrepresents" the identity of the speaker/s; each descending level presents an increasingly complex "picture" of identity (го). Ellen Badone applies Cohen's concept of ascending and descending levels to her data on geographic social groupings in Brittany and argues that "identity

${ }^{1}$ Fredrik Barths (1969) found that this lack of awareness of cultural variation between similar communities is typical of most ethnic groups, including the Pathans with whom he worked.

${ }^{2}$ In fact, first-person singular is used only very rarely in everyday Chhattisgarhi conversation. Its use has the implications of drawing attention to oneself as distinct from one's family and/or community, which is rarely appropriate. 
needs to be conceptualized in terms of a series of nested local, regional and national levels" (I987: I 86).

There is a distinct difference in the levels of inclusivity assumed in male and female speech/commentary about Chhattisgarhi folklore genres. Male informants tend to associate themselves with a broader spectrum of genres in which they do not directly participate as performers than do women; they characteristically identify genres with the wider communities of which they are a part, such as village or region, rather than with the more limited folklore group of performers only. When I was asking general questions about repertoire, Chhattisgarh men often told me that "we sing the sua nāc," a genre performed exclusively by women. The "we" was used to refer to a social group based upon decisive factors other than the gender of the performers. Women rarely identify themselves in this inclusive sense with male genres, and they spoke "on behalf of" the Chhattisgarh region less frequently than did their male relatives. This phenomenon may be partially attributed to the fact that women have less physical mobility than men and thus identify with more limited communities. It may also be due in part to the secondary position that women occupy in the social hierarchy; those higher in the hierarchy (caste, age, as well as gender hierarchies) more easily co-opt the traditions of those below them in such discussions than vice versa.

\section{Performative Identification of Social Categories}

We have seen in the discussion of bhojali that the social organization of genre-the folklore groups identified through performance-suggest indigenously perceived significant social categories within the larger community; the social and aesthetic organizations reinforce each other (Abrahams 1976:194). The identification in Phuljhar of bhojali as an unmarried girls' genre suggests that the social category of pubescent girls is a marked one in this subregion; the absence of genres so identified on the Raipur plains suggests that unmarried girls are "counted" in the category of married women. This principle is further exemplified in the comparison of social distinctions marked in the performance of bhojali and a related male goddess tradition called javārā on the Raipur plains (see Figure I). In both festivals, wheat or barley seedlings are planted, allowed to grow for nine days, and worshiped as the goddess; the presence of the goddess is affirmed through her possession of her devotees. The primary difference between the two festivals is that women sing the songs associated with the worship of the goddess in bhojali and men sing javärä songs.

By placing these two traditions in relationship, we observe that gender is 


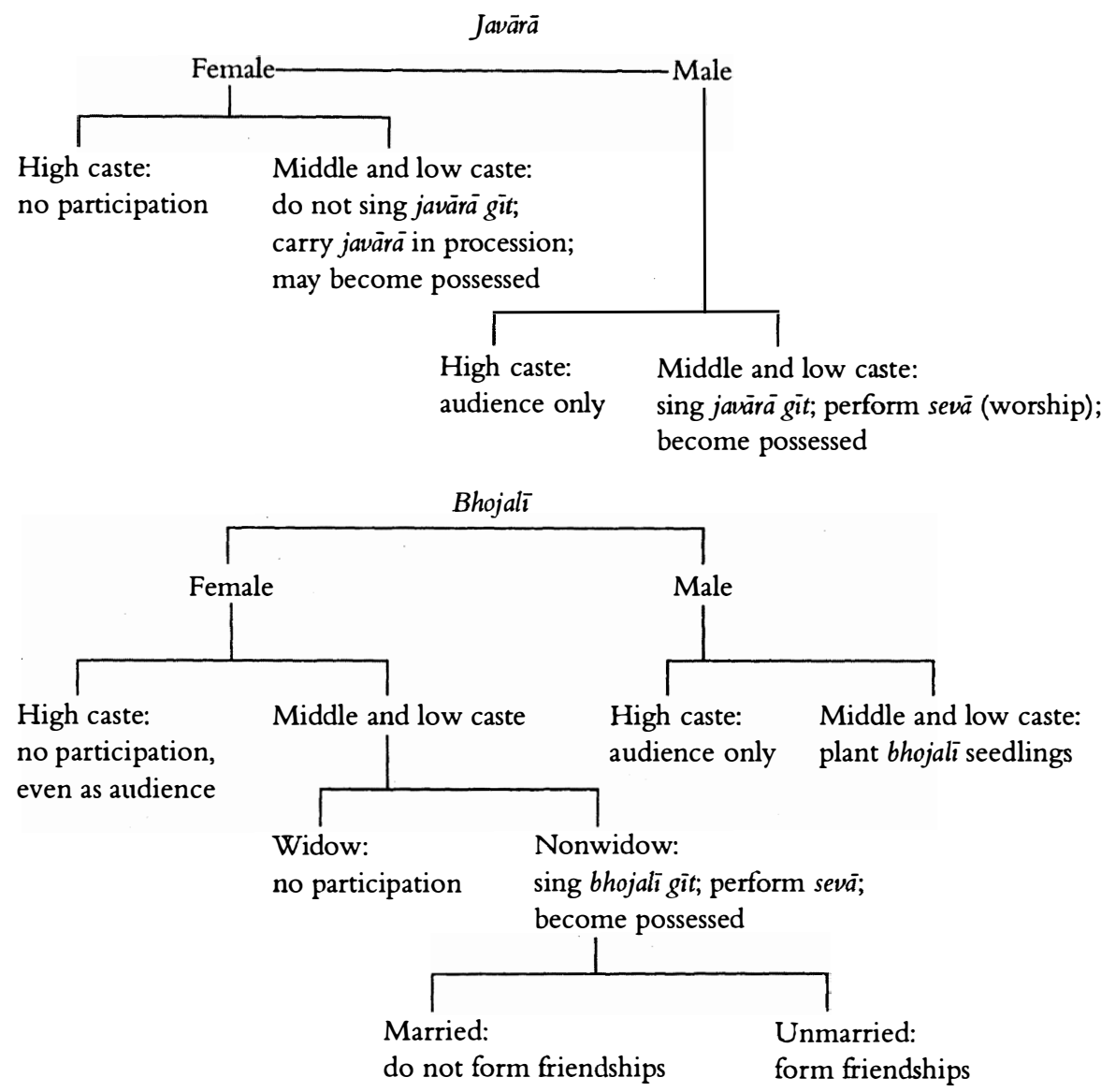

Figure 1. Social organization of bhojali and javāan performance on the Raipur plains

the primary social division in the folklore community. Gender distinction is characteristic of the Chhattisgarhi regional folklore system as a whole; although audiences may be mixed, no traditions exist (at least in the Hindu community) in which men and women perform together. In dramatic genres with female characters, such as the $n \bar{a} c \bar{a}$ dance-drama, female parts are played by males in female dress.

Next, a caste distinction among both javāra and bhojali participants is indicated, although it is less accentuated in the male javara $\bar{a}$ tradition than in the female bhojali. Among female performers of bhojati, there are no high- or even middle-caste women represented; they say they are afraid of becoming possessed by the goddess if they participate in the festival at any level, even as observers. As one woman articulated, "You never know what will happen." 
Women who become possessed at festivals such as bhojali and gaurā often have with them a female companion who adjusts the devotee's sari and physically keeps her from falling down so that she remains modest. Whether or not possession is present, however, women of different caste levels rarely perform together in genres belonging to the Chhattisgarhi repertoire. ${ }^{3}$ In the javāa tradition, men of all caste levels may participate in some way, as audience, singers, and/or devotees of the goddess. Caste distinction as it is observed through the organization of the folklore system is typically less pronounced among men than women; ${ }^{4}$ men also perform together in other folklore genres, such as candainī nācā dance-dramas and bhajan (devotional) singing groups.

The social groups identified by bhojalī-javārā performance further suggest that the marital status of a male is less significant as that of a female. Males are rarely segregated by their marital status for participation in most genres, widowers are not excluded from participation, and unmarried boys have no unique public-performance genres, participating with the married men in such performances. The female bhojali tradition, on the other hand, differentiates between categories of widow and nonwidow as well as married and unmarried: widows may not participate, and while unmarried girls sing the bhojali songs in the company of married women, only unmarried girls ritualize a bhojali friendship at the conclusion of the festival.

\section{Shifting Boundaries of Genre and Community}

Increasing literacy, the spread and popularity of mass media communication, and shifting social institutions and economic and social relationships between patrons, performers, and audiences are affecting and changing traditional associations between many folklore genres and their communities. Songs that used to be sung and heard primarily by women may now be heard blasting loudly over All India Radio's folklore programming in public contexts. In many villages, professional dance-drama troupes, epic singers, and storytellers are having to compete with "video halls" (any kind of structure

${ }^{3}$ I specify genres within the Chhattisgarhi repertoire because of the relatively recent emergence of the temple-based, multicaste Ramayana mandali (singing groups); when such mandali meet in private homes, however, they are still restricted to a shared caste level, if not specific jäti.

${ }^{4}$ Edward Henry does not find this caste distinction in female performance in the Bhojpuri-speaking region of north India, where, he writes, "Women's songs move easily between castes" (1988:107). However, he does not indicate if he means that they perform together or perform the same genre separately or if he is speaking of specific jäti or caste levels. 
to which admittance is charged to view a Hindi film shown with a video machine), and more recently with the increasingly available and affordable television. In 1993 when I asked the leader of a men's singing troupe that performs primarily rämsaptah, and less frequently pandvāni, which was more popular in Chhattisgarh, Ramayana or pandvānī, he sighed, "Pandvānī, Ramayana, candainī. But yes, whatever there is, lok sāhitya, lok sanskṛti [folklore and folk customs], it's all finished now with TV. You'll get very little of it. Whatever it is-nāca-wāca-now there's [only] video." 5

Formal school education of more and more audience members has resulted in a decreased interest in certain performance genres and a reemergence or realignment of other genres. Accompanying increased literacy has been the development of a perception of what it means to "act literate," action that may preclude participation in certain performances and festivals. For example, the primary reason given by male village elders for the demise of dâlkhāi as a festival tradition is that "our educated girls shouldn't be singing these songs." As we have seen, though, while increasing literacy seems to have had an indirect detrimental effect for the festival setting for the songs, the song tradition itself is alive and well outside the ritual setting. As the performance context has shifted, so, too, has the identity of the community with which the genre is associated; the genre is now identified more frequently with the Phuljhar folklore community of eastern Chhattisgarh, male and female, rather than with the folklore group of unmarried Oriya girls. It is called a "Phuljhar song," or an "Oriya song," more often than it is a "holi song for unmarried girls."

In the sū nāc we saw a second example of shifting boundaries and identification of social groups with a particular folklore genre. The tradition has undergone numerous changes in performance context during the years in which I have done fieldwork in Chhattisgarh and is an example of the ascending and descending levels of identification with a single genre. Although the dancers (that is, the folklore group) are a divāsi women, crucial to the definition of the genre in its dance context is its non-ädivāsi "audience" and the channel established between performers and patrons for the exchange of auspicious blessings and the gifting of grain and cash.

Because of the many levels of participation in the tradition, as well as its wide geographic spread throughout the region, the sua $n \bar{a} c$ is an important genre in helping to define the Chhattisgarh folklore region. And it is on this

5 The use of an "echo word" (in this case, wāca) in Hindi and its dialects indicates the general category into which the first word of the pair fits. So nācā-wācā implies nācā and other similar performance genres, or $p \bar{a} n-w \bar{a} n$ indicates those things that are consumed along with pān. 
level that the genre is often identified by male informants, first as a Chhattisgarhi genre and only later as a female or ādivāsi tradition. Upper-caste women, on the other hand, most often identify it as an àdivāsi dance. Meanwhile, ádivāsi women themselves are frequently more specific as to the nature of the social group to whom the dance belongs-according to the jati of the participants (beyond the general category of ādivāsi ), their village or neighborhood, or the nature of their vow to the goddess the previous year, for whose fulfillment a particular woman may be participating as a dancer.

Increased literacy, changing social conditions, and mass media technology (particularly radio) have all made an impact on the genre of sūa nāc and the communities with which it is identified. In Dhamtari young high school graduate Gond women (or perhaps it is their families) did not feel it appropriate to dance in public as do the sua nāc troupes. Further, because there is not a traditional, ritual relationship between dancers and shopkeepers in the urban areas, many other women, particularly the older ones, no longer want to dance in that context. As I mentioned earlier, several Gond women in the town of Dhamtari asserted, "People think we'll dance, but why should we?" The women dancing the sua nāc in urban neighborhoods are aware at some level that the genre gives identity to their caste, as well as reflecting and giving voice to their interests as women. Thus, as traditional settings for the dance are eroding in the towns and cities, its performers have discovered innovative contexts in which to maintain the tradition in order also to maintain their community, specifically the gaura festival for whose images the suā nāc traditionally raised funds.

Because of its popularity throughout Chhattisgarh and its various levels of performative identification, the sūa $n \bar{a} c$ is one of the genres frequently performed and recorded for the folklore programming of All India Radio. So while "live" performances, particularly in the urban areas, may be becoming more private or limited, recorded performances that are broadcast are available to all as audience, regardless of caste, gender, or education level. Similarly, two performance settings have also emerged for the candaini and pan$d v \bar{a} \bar{\imath}$ epic genres: one in village courtyards and squares, and the other on public airwaves or on the proscenium stage in front of upper-middle class, educated audiences.

Although the relationship between genre and community is a strong indigenous organizing principle of the Chhattisgarhi folklore system, we have seen that it is not a static one. An indigenous awareness of the power of performance to identify and sustain community is found on numerous levels throughout Chhattisgarh. In a discussion with a rather young village headman (age forty-five) who had come to his position through the recent acquisition of land rather than hereditarily, he talked specifically about the 
role he thought folklore could play in establishing a sense of village identity and in improving village morale. He told me he had introduced the gaura festival to his village only seven to eight years earlier. Many of the daughtersin-law marrying into his village come from villages in which gaura is a vibrant tradition, but for some reason it had not been celebrated in this village. So the headman asked the women if they would be willing to introduce gaura to their village of marriage. He thought this festival, specifically, would increase village cohesion because of the numerous folklore groups it could involve and the large public procession to the village tank that ends the festival. After several years of gaura celebration in the village, the headman was satisfied with the results it had brought and was thinking of other new villagewide traditions that he could sponsor and "cause to be introduced."

Modern education and an effort by Chhattisgarhi literati to place Chhattisgarhi folklore within the broader schema of pan-Indian folklore have introduced another organizing principle to the Chhattisgarhi folklore system, alongside that of performative communities. This is one based on formal distinctions; its categories are gìt, kahānī/kathā, and nățak/nācā (song, story, drama). All India Radio's folklore programming also relies on these distinctions. Although the terms gìt and kahāni are currently used by members of Chhattisgarh's folklore communities, they are not distinguishing categories of genre. It remains to be seen whether this system of formal genres will be adapted more fully by Chhattisgarhi performers and audiences in their oral commentary and metafolklore, together with or replacing that of genre and community.

Recognizing indigenous genres and categories, their stability and flexibility, suggests frames through which a scholar from outside a particular folklore system can begin to explore the interior of performance texts in ways that are consistent with indigenous perceptions and understandings. In the folklore region of Chhattisgarh, a central principle characterizing its repertoire has been the social organization of genres. The changes that are restructuring traditional associations between gender, genre, and community have begun, however, to redefine and alter the interpretive frames of indigenous genres, and to affect the meanings of their performance. 


\section{PERFORMANCE TEXTS}


